University for Business and Technology in Kosovo

UBT Knowledge Center

UBT International Conference

2017 UBT International Conference

Oct 28th, 2:30 PM - 4:00 PM

\title{
The Antimicrobial Resistance of the Bacterium Salmonella Enteritidis Isolated from Poultry for the Production of Eggs in Kosovo
}

\author{
Hyzer Rizani \\ University for Business and Technology \\ Syzana Aliu \\ University for Business and Technology \\ Besart Jashari \\ Food and Veterinary Agency, Pristina, Kosovo \\ Magbule Rizani \\ University for Business and Technology \\ Shkëlzim Ukaj \\ University for Business and Technology
}

See next page for additional authors

Follow this and additional works at: https://knowledgecenter.ubt-uni.net/conference

Part of the Food Science Commons

\section{Recommended Citation}

Rizani, Hyzer; Aliu, Syzana; Jashari, Besart; Rizani, Magbule; Ukaj, Shkëlzim; Shala, Shkumbin; and Feka, Fidan, "The Antimicrobial Resistance of the Bacterium Salmonella Enteritidis Isolated from Poultry for the Production of Eggs in Kosovo" (2017). UBT International Conference. 155.

https://knowledgecenter.ubt-uni.net/conference/2017/all-events/155

This Event is brought to you for free and open access by the Publication and Journals at UBT Knowledge Center. It has been accepted for inclusion in UBT International Conference by an authorized administrator of UBT Knowledge Center. For more information, please contact knowledge.center@ubt-uni.net. 


\section{Presenter Information}

Hyzer Rizani, Syzana Aliu, Besart Jashari, Magbule Rizani, Shkëlzim Ukaj, Shkumbin Shala, and Fidan Feka 


\title{
THE ANTIMICROBIAL RESISTANCE OF THE BACTERIUM SALMONELLA ENTERITIDIS ISOLATED FROM POULTRY FOR THE PRODUCTION OF EGGS IN KOSOVO.
}

\author{
Hyzer Rizani ${ }^{1}$, Naser Kamberi ${ }^{1}$, Besart Jashari ${ }^{2}$, Magbule Rizani ${ }^{1}$, Shkëlzim Ukaj ${ }^{1}$, \\ Shkumbin Shala ${ }^{1}$ \\ ${ }^{1}$ UBT - Higher Education Institution, Lagjja Kalabria, 10000 p.n., Prishtine, \\ Kosovo \\ ${ }^{2}$ Food and Veterinary Agency, the Food and Veterinary Laboratory, Pristina, Kosovo \\ Magbule Rizani e-mail:mr31108@ubt-uni.net
}

\begin{abstract}
Salmonella Enteritidis represents a group of bacteria known to cause typhoid fever, food poisoning, gastroenteritis, enteric fever, and other diseases in humans. People are mainly infected with contaminated water or foods, especially meat, chicken meat and eggs. Salmonella gender includes over 2300 bacterial serotypes. Salmonella enteritidis and Salmonella typhimurium are responsible for over $50 \%$ of all infections caused in people anywhere in the world. The purpose of the study is to determine the sensitivity and resistance to antibiotics of some isolated strains of Salmonella enteritidis in private farms and eggs for egg production in several parts of Kosovo. Isolation and identification is done according to ISO 6579: 2002. The antibiotic test was performed on 13 strains of Salmonella enteritidis with the Kirby-Bauer method. Disk diffusion test method must be in compliance with the standard of CLSI clinical institutes and laboratories. Mueller Hinton agar was used with antibiotic disks of various groups where we obtained these results in sensitivity and resistance: Gentamicin 10mcg-S / 66.2\%, I / $12.4 \%$ and R / 21.4\%, Trimethoprim-sulfamethoxazoleSxt $25 \mathrm{mcg}-\mathrm{S} / 33.4$, I / 48.3\% and R / 18.3\% Ampicillin Amp 2 mcg S / 15.6\%, I / 23.5 and R- 60.9\% and Cephalexin CL 30mg-S / 16.4 , I / 77 and $\mathrm{R} / 6.6 \%$.
\end{abstract}

Keywords: Salmonella, I-intermediate, resistance, strain, sensitivity.

\section{INTRODUCTION}

In the research we have done antibiotics-resistance of Salmonella enteritidis in the samples of eggs, stool and bodies in farms and the poultry region of Lipljan, Shtime and Ferizaj-Kosova to create an overview presence of this pathogen in these types of samples and determinationof sensitivity to certain antibiotics. Salmonella enteritidis is a gram-negative bacterium rod shaped known as the cause of the prevalence of diarrheal disease in humans (Çabeli, P. a. (2006). Humans become infected mainly between contaminated water or food, especially meat, poultry and eggs. Moreover, the growth of fast food consumption of animal productsand the international trade between countries have also played an important role in the spread of S. enteritidis (Landeras et al., 1998). S. enteritidis can also be spread in the environment by fecal contamination of human beings and animals (Okafo et al., 2003).

Due to major economic losses, as well as public health problems, detection and eradication of S. enteritidis from chicken farms is of primary importance. The large usage antibiotics can cause 
the selection and spread of resistant pathogens as S.enteritidis that are transmitted to humans through different contaminated food (ESRB H, CA (2005). The conventional methods for Salmonella detection are based on cultures by using the enrichment of selective and half selective media and characterization of suspicious colony from biochemical and serological tests of S.enteritidis. Serotyping is an important tool to understand the epidemiology of infections caused by Salmonella genus species, which takes place under the scheme of White Kaufmanit (1920), based on the discovery of flagellar $\mathrm{H}$ antigen, somatic $\mathrm{O}$ antigen and the surface, Vi (Cabeli P., 2006).

\section{MATERIAL AND METHODS}

The study is made on the Laboratory Agency of Food and Veterinary in Kosovo. The study was conducted in the period, from March to October 2014, with the samples of eggs, stool, and organs. A total of 312 samples were investigated, from 13 isolated strains of Salmonella enteritidis. There have been tested 13 Salmonella enteritidis strains in sensitivity and resistance to various groups of antibiotics. Testing is performed by Kirby-Bauer, a disk diffusion method in accordance with the CLSI standards [1].

The used material for testing: the ground Mueller Hinton Agar 2 rehydrated in plates of $90 \mathrm{~mm}$, $\mathrm{NaCl}$ 0.9\%, antibiotics, Gentamicin 10mcg, Trimethoprim-sulfamethoxazole SXT $25 \mathrm{mcg}, 2 \mathrm{mcg}$ Amp Ampicillin, Cephalexin CL and 30mg.

S.enteritidis strains are prepared in advance on the enrichment ground of BPW, then are transferred in plates of MHA- 2 where the extension is done uniformly across the surface of the platter. Later are placed the antibiotics drives at a certain distance and the plates are inserted in incubation- $370 \mathrm{C}$ for 24 hours. After incubation, the results are examined by the measurements using the nonius (calliper) for each disk (antibiotic).

\section{RESULTS AND DISCUSSION}

The results obtained in this study, as are shown in the tables below, which are investigated the stool samples, organ samples, samples of eggs and 13 isolated strains of Salmonella enteritidis. All these strains were isolated by the standard method ISO 6579: 2002. These strains of Salmonella enteritidis were tested by antibiogram method. The results obtained for strains in the study were as follows: $66.2 \%$ sensitivity gentamicin, the antibiotic sulfamethoxazole $33.4 \%$. Salmonella enteritidis strains showed the highest resistance to Ampicillin 60.9\%, while the average sensitivity is shown $77 \%$ antibiotic cephalexin. 
Table.1. The expression in percentage of the sensitivity of Salmonella enteritidis resistance to some antibiotics.

\begin{tabular}{|c|c|l|l|l|l|l|l|l|l|}
\hline \multirow{2}{*}{$\begin{array}{c}\text { Regi } \\
\text { on }\end{array}$} & $\begin{array}{c}\text { Strai } \\
\text { ns }\end{array}$ & \multicolumn{2}{|l|}{$\begin{array}{l}\text { Gentamicin } \\
10 \mathrm{mcg}\end{array}$} & \multicolumn{2}{l|}{$\begin{array}{l}\text { Trimethoprim- } \\
\text { sulfamethoxaz } \\
\text { ole Sxt 25 mcg }\end{array}$} & \multicolumn{2}{l|}{$\begin{array}{l}\text { Ampicilin Amp } \\
2 \mathrm{mcg}\end{array}$} & \multicolumn{2}{l|}{$\begin{array}{l}\text { Cephalexin CL } \\
30 \mathrm{mg}\end{array}$} \\
\cline { 3 - 10 } & & $\begin{array}{l}\text { Sensiti } \\
\mathrm{v}\end{array}$ & $\begin{array}{l}\text { Resist } \\
\text { ent }\end{array}$ & $\begin{array}{l}\text { Sens } \\
\text { itiv }\end{array}$ & $\begin{array}{l}\text { Resist } \\
\text { ent }\end{array}$ & $\begin{array}{l}\text { Sensit } \\
\text { iv }\end{array}$ & $\begin{array}{l}\text { Resist } \\
\text { ent }\end{array}$ & $\begin{array}{l}\text { Sensit } \\
\text { iv }\end{array}$ & $\begin{array}{l}\text { Resist } \\
\text { ent }\end{array}$ \\
\hline Total & 13 & $66.2 \%$ & $21.4 \%$ & $\begin{array}{c}33.4 \\
\%\end{array}$ & $18.3 \%$ & $\begin{array}{c}15.6 \\
\%\end{array}$ & $60.9 \%$ & $\begin{array}{l}16.4 \\
\%\end{array}$ & $6.6 \%$ \\
\hline
\end{tabular}

These strains of Salmonella enteritidis were tested by the antibiogram method. The results obtain

ed for strains in the study were as follows: $66.2 \%$ sensitivity gentamicin, the antibiotic sulfamethoxazole $33.4 \%$. Salmonella enteritidis strains showed the highest resistance to Ampicillin $60.9 \%$, while the average sensitivity is shown $77 \%$ for the cephalexin antibiotic.

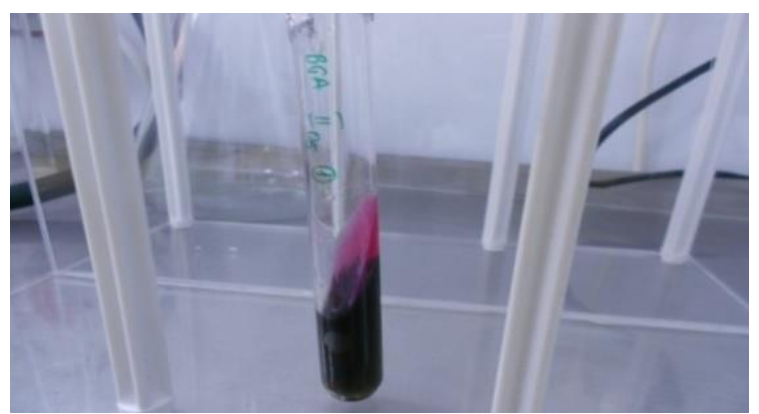

Fig. 1. Salmonella enteritidis, the TSI agar

As seen from the table above, 13 Salmonella strains enteritidis in the study were tested in the Laboratory Agency of Food and Veterinary in Kosovo, the method of Kirby Bauer's showed these results in sensitivity, $66.2 \%$ gentamicin $10 \mathrm{mcg}$, and less sensitive to Trimethoprimsulfamethoxazole $33.4 \%$ SXT $25 \mathrm{mcg}$, resistan is shown to the antibiotic Ampicillin Amp $2 \mathrm{mcg}$ with $60.9 \%$ and the average sensitivity antibiotic cephalexin CL $30 \mathrm{mg}$ with $77 \%$. Salmonella enteritidis strains continue to be resistant toantibiotic Ampicillin where from the 32 isolates, 21 are presented for resistance to the antibiotic Ampicillin or expressed in percentage $65.62 \%$ in national center for toxicological research in Iraq (Mezal EH, 2013).

\section{CONCLUSIONS}

Isolation, identification and determination of sensitivity and resistance of Salmonella enteritidis in three regions determines not only the number of the bacteria and their geographical distribution, epidemiological consequences, economic and health.

- From the total of 312 total samples analyzed, by the method ISO 6759: 2002 in three regions in the study found a prevalence of Salmonella enteritidis, about 13 strains or $4.16 \%$ of total samples analyzed

- Comparing the presence of Salmonella enteritidis by the total isolated Salmonella strains spp., appears that Salmonella enteritidis has a prevalence of $46.4 \%$. 
- The highest percentage is found in faeces, from which 10 strains were isolated or $76.92 \%$, in organs were isolated two strains or 15:38\% and in eggs are isolated 1 strains with 7.69\%. The gained results on strains of Salmonella enteritidis with sensitivity testing and antimicrobial resistance are as follows:

- Salmonella enteritidis has shown great sensitivity to the antibiotic Gentamicin $10 \mathrm{mcg}$ in percentage $66.2 \%$, also slightly lower percentage of sensitivity shown in antibiotic Trimethoprim-sulfamethoxazole SXT $25 \mathrm{mcg}$ with antibiotic cephalexin $33.4 \%$ and $15.6 \% \mathrm{CL}$ 30 with.

- Salmonella enteritidis strains are resistant to the antibiotic Ampicillin Amp 2 mcg with percentage of $60.9 \%$.

- While the antibiotic cephalexin CL $30 \mathrm{mg}$ of Salmonella enteritidis strains presented intermediate $77 \%$, also in antibiotic Trimethoprim-sulfamethoxazole SXT $25 \mathrm{mcg}$ presented a percentage of $48.3 \%$.

The first results show that the use of antibiotics in poultry industry in Kosovo becomes uncontrolled. This underlines the need to use antibiotics carefully in veterinary practice to avoid growing antibiotics problems and resistance in human medicine, as well.

\section{REFERENCES}

1. Çabeli, P. a. (2006). Bakteriologjia-Mykologji Veterinare.Tirana Agricultural University

2. F. Polo a, M. F., \& *, I. I. (2006, January 17). http://onlinelibrary.wiley.com.

Retrieved from http://onlinelibrary.wiley.com/doi/10.1111/j.15746968.1998.tb12919.x/references.

3. Bauer KA, J Sherris, M Turk.: Antibiotic susceptibility testing by standardized single disc method.Amer. J Clin Pathol, 1966 45: 493-496.

4. Jan Hudzicki: Kirby-Bauer Disk Diffusion Susceptibility Test Protocol. American

Society for Microbiology, Washington, DC 2009, Accessed 10 September 2010

5. Salm-Surv, G. (2003). Laboratory Protocols . In R. S. Hendriksen, Laboratory Protocols Level

6. Training Course Identification of Salmonella. Global Salm-Surv.

7. Mezal EH, Sabol A, Khan MA, Ali N, Stefanova R, Khan AA. Isolation

andmolecular characterization of Salmonella enterica serovar Enteritidis from poultry house and clinical samples during 2010. Food Microbiol. 2014Apr;38:67-74. doi:

10.1016/j.fm.2013.08.003. Epub 2013 Aug 27. PubMed PMID:24290628.

8. Lu Y, Wu CM, Wu GJ, Zhao HY, He T, Cao XY, Dai L, Xia LN, Qin SS, Shen JZ. Prevalence of antimicrobial resistance among Salmonella isolates from chicken in China.

Foodborne Pathog Dis. 2011 Jan;8(1):45-53. doi: 10.1089/fpd.2010.0605.Epub 2010 Nov 17. PubMed PMID: 21083518.

9. Threlfall EJ, Frost JA: Plasmid profile typing can be used to subdivide phage type 49 of Salmonella typhimurium outbreakinvestigation. Epidemiol Infect 1990, 104: 243-51.

10. Landeras, E., A. Gonzales-Hevia and C. Mendoza, 1998. Molecular epidemiology of Salmonella serotype enteritidis relation ship between food water and pathogenic strains. Int. J. Food Microbiol., 43: 81-90.

11. Okafo, C.N., V. Umoh and M. Galadima, 2003. Occurrence of pathogens on vegetables harvested from soils irrigated with contaminated streams. Sci. Total Environ., 311: 49-56. 
14. Vaz CS, Streck AF, Michael GB, Marks FS, Rodrigues DP, Dos Reis EM, CardosoMR, Canal CW. Antimicrobial resistance and subtyping of Salmonella enterica subspecies enterica serovar Enteritidis isolated from human outbreaks and poultryin southern Brazil. Poult Sci. 2010 Jul;89(7):1530-6. doi: 10.3382/ps.2009-00453.PubMed PMID: 20548083.

15. Vegle H, C. A. (2005). Emergence of Salmonella epidemics: The problem realted to Salmonella Enterica serotype Enteriditis and multiple antibiotic resistance in other major serotypes. Veterinary Research 36,267-288.

16. Hulaj Beqe, Çabeli Pranvera, Goga Izedin, Shtylla Tana.: Isolation, identification and prevalence of Salmonella spp. in some poultry farm for egg production in Kosovo Albanian j.agric.sci. ISSN: 22182020,(2012), (Special Edition) Copyright @ Agricultural University of Tirana.

17. Vegle H, C. A. (2005). Emergence of Salmonella epidemics: The problem realted to Salmonella Enterica serotype Enteriditis and multiple antibiotic resistance in other major serotypes. Veterinary Research 36,267-288.

18. Programme, J. F. (2010). CODEX ALIMENTARIUS COMMISSION. Rome,Italy: FAO/WHO 